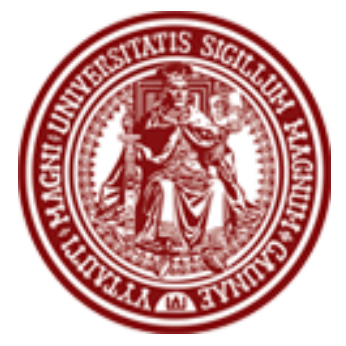

BALTIC JOURNAL OF LAW \& POLITICS

VOLUME 3, NUMBER 2 (2010)

ISSN 2029-0405

http://www.versita.com/science/law/bjlp

Cit.: Baltic Journal of Law \& Politics 3:2 (2010): 1-25

DOI: $10.2478 / \mathrm{v} 10076-010-0008-6$

\title{
HUMAN RIGHTS GUARANTEES DURING STATES OF EMERGENCY: \\ THE EUROPEAN CONVENTION ON HUMAN RIGHTS
}

\author{
Stefan Kirchner \\ Research Assistant \\ Georg August University, Faculty of Law (Germany) \\ Doctoral Student \\ Justus Liebig University, Faculty of Law (Germany)
}

\begin{abstract}
Attorney at Law (Rechtsanwalt, admitted to the bar in Germany) Rechtsanwaltskanzlei Kirchner, Antrifttal (Germany)

\section{Contact information}

Address: Georg-August-University, Chair for Public Law, in particular Religious Law and the Constitutional Law of Religious Communities, Gosslerstrasse 11, 37073 Göttingen, Germany

Phone: $+49(176) 23890182$

E-mail address: kanzlei@stefankirchner.org, kirchnerlaw@yahoo.com
\end{abstract}

Received: July 02, 2010; reviews: 2; accepted: November 25, 2010.

\section{ABSTRACT}

As is the case with other international human rights treaties, the European Convention on Human Rights (ECHR) offers states parties to the convention possibilities to limit the exercise of human rights in times of crisis. The margin of appreciation doctrine employed by the European Court of Human Rights gives states a lot of leeway in applying the Convention domestically. The question is whether the Convention also allows states to restrict rights guaranteed under the Convention to a degree which would be inconsistent with the spirit of the Convention. To answer the question whether human rights are sufficiently guaranteed under the Convention even in times of emergencies we will first look at general rules concerning the restriction of rights under the Convention. We will then move our investigation to Art. 15 ECHR and look at the conditions set by the norm, its limits as well as at some special cases of emergencies. 


\section{KEYWORDS}

European Convention on Human Rights, European Court of Human Rights, limitations of human rights, state of emergency, crisis, margin of appreciation, Article 15 ECHR

\section{NOTE AND ACKNOWLEDGEMENT}

This text is an extended version of the presentation given by the author at the March 26, 2010 conference on the state of exception at Vytautas Magnus University in Kaunas, Lithuania. The author thanks the participants of that conference for the interesting discussions in the wake of the presentation of this paper, in particular J. D. Mininger, T. Berkmanas, C. Szymanski, E. Hartz and T. Pepper. 


\title{
INTRODUCTION
}

\author{
As is the case with many international human rights treaties ${ }^{1}$ the European
} Convention on Human Rights ${ }^{2}$ (ECHR) offers states' parties to the convention ${ }^{3}$ possibilities to limit the exercise of human rights in times of crisis. Just how far the Convention goes is the question.

The margin of appreciation doctrine ${ }^{4}$ employed by the European Court of Human Rights (ECtHR) gives states a lot of leeway in applying the Convention

${ }^{1}$ Cf. Matthias Maslaton, Notstandsklauseln im regionalen Menschenrechtsschutz: Eine vergleichende Untersuchung der Art. 15 EMRK und Art. 27 AMRK, $1^{\text {st }}$ ed. (Frankfurt am Main: Peter Lang, 2002).

${ }^{2}$ Available online at:

http://www.echr.coe.int/ECHR/EN/Header/Basic+Texts/The+Convention+and+additional+protocols/The +European+Convention+on+Human+Rights/ (last visited 14 May 2010). On the law of the European Convention on Human Rights see among the vast existing literature David J. Harris, Michael O'Boyle, Edward Bates, and Carla Buckley, Harris, O'Boyle \& Warbrick Law of the European Convention on Human Rights, $2^{\text {nd }}$ ed. (Oxford: Oxford University Press, 2009); Steven Greer, The European Convention on Human Rights: achievements, problems and prospects, $1^{\text {st }}$ ed. (Cambridge: Cambridge University Press, 2006); John G. Merrills and Arthur H. Robertson, Human Rights in Europe: a study of the European Convention on Human Rights, $4^{\text {th }}$ ed. (Manchester: Manchester University Press, 2001); Franz Matscher and Herbert Petzold, eds., Protecting Human Rights: the European dimension: studies in honour of Gérard J. Wiarda, $2^{\text {nd }}$ ed. (Cologne: Carl Heymanns Verlag, 1990).

${ }^{3}$ Unlike some in the case of some other multilateral legal instruments created by the Council of Europe $(\mathrm{COE})$, the international organisation behind the ECHR, only states which are members of the CoE can become parties to the ECHR. In fact, the ratification of the ECHR is expected from all new CoE members as soon as possible after joining the CoE. Membership in the CoE is open to all states which have at least part of their territory on the European continent. While Russia, Armenia, Azerbaijan and Turkey are already full members of the CoE, Kazahkstan, the westernmost part of which is located west of the Ural mountains and thereby in Europe in a geographical sense (cf. Situation in Kazahkstan and its relations with the Council of Europe, Council of Europe Parliamentary Assembly, Council of Europe Document 11007,7 July $2006 / /$

http://assembly.coe.int/Main.asp?link=/Documents/WorkingDocs/Doc06/EDOC11007.htm (accessed May 28,2010 ) is not a member. Just days before the conference at which this paper was presented, talks were underway to strengthen to cooperation between Kazahkstan and the CoE, bringing the Central Asian country closer to Europe (PACE President in favour of strengthening relations with Kazahkstan, Council of Europe Parliamentary Assembly, 16 March 2010 //

http://assembly.coe.int/ASP/NewsManager/EMB_NewsManagerView.asp?ID=5361\&L=2 (accessed May $28,2010)$. Kosova has not yet applied for CoE membership, primarily due to the fact that it is not recognized as an independent state by several CoE members. The application by Belarus has been put on hold since the undemocratic elections in 1996. While the Vatican is a state but not a member, the Holy See, which is an ancient subject of Public International Law sui generis and distinct from the much younger state of the Vatican City, and which is (also in order to ensure continuity even in the eventual absence of territory) the legal tool through which the Catholic church is traditionally conducting her international affairs, has observer status. Observer status with the CoE (at large) is also enjoyed by Canada, Japan, Mexico and the United States of America while Canada and Mexico also have observer status at the CoE's parliamentary assembly, as has Israel. More controversially, on occasions of local concern, even representatives of the Palestinian Legislative Council, which is de jure responsible for certain areas of Samaria and Judea as well as for the Hamas-controlled Gaza strip can be invited. Under Resolution 1113 (1997), the Parliamentary Assembly also invited representatives of the de facto regime in the so called Turkish Republic of Northern Cyprus (TRNC), which lacks the qualities of statehood due to a complete non-recognition by all other states (on collective non-recognition and the Cyprus issue (cf. Stefan Talmon, Kollektive Nichtanerkennung illegaler Staaten, $1^{\text {st }}$ ed. (Tübingen: Mohr Siebeck, 2006), p. 10 et seq.) except Turkey for which it acts as a tool for the continued implementation of the illegal occupation of Cyprus, have been invited, albeit not as representatives of the TRNC but as "representatives of the Turkish Cypriot Community" (Resolution 1113 (1997) on the Situation in Cyprus, Council of Europe Parliamentary Assembly, 29 January 1997 //

http://assembly.coe.int/Main.asp?link=/Documents/AdoptedText/ta97/ERES1113.htm (accessed May 28,2010 )

${ }^{4}$ On the margin of appreciation doctrine cf. Ireland $v$. United Kingdom, ECtHR Judgment of 18 January 1978; Eva Brems, "The Margin of Appreciation Doctrine in the Case-law of the European Court of Human Rights," Zeitschrift für ausländisches öffentliches Recht und Völkerrecht 56 (1996); Johan Callewaert, "Is there a Margin of Appreciation in the Application of Articles 2, 3 and 4 of the Convention?," Human Rights Law Journal 19 (1998); Michael R. Hutchinson, "The Margin of Appreciation Doctrine in the European Court of Human Rights," International and Comparative Law Quarterly 48 (1999); Michael 
domestically. The question is therefore whether the Convention also allows states to restrict rights guaranteed under the Convention to a degree which would be inconsistent with the spirit of the Convention. That this possibility is not so farfetched becomes evident when we look at the perversion of justice which has already been allowed to happen under the umbrella of the margin of appreciation doctrine in the context of Art. 2 of the Convention. Art. 2 ECHR guarantees "everyone's" right to life - without restriction. ${ }^{5}$ The term "everybody" obviously refers to all humans. Nevertheless the Court has refrained from stating the obvious, namely that abortion is incompatible with Art. 2 of the Convention. If it would be legal, there would have been an exception to this effect already included within the norm, which is not the case. The Court justifies its failure to apply the law according to its wording with the lack of agreement between the member states on this issue. In giving states that much of an opportunity to deviate from the wording of the Convention, the Court has shown that it is at risk of being abused by states at the cost of individual human rights holders. Abortion is incompatible with the wording of Art. 2 (1) ECHR. Yet, most states' parties to the Convention allow abortion in one way or another. But that does not mean that abortion has suddenly become legal despite the wording of Art. 2 (1) ECHR. ${ }^{6}$ To the contrary, it means that currently only Malta and Ireland can be considered as fulfilling their obligations under the Convention in this respect. But if the mere divergence of views between different member states de facto prevents the Court from clearly stating the law, it has to be feared that the Court might also be willing to grant states too much freedom to restrict human rights if they claim some kind of emergency and allege that this emergency makes it necessary for them to do so. One step in this

O'Boyle, "The Margin of Appreciation and Derogation under Article 15: Ritual Incantation or Principle?," Human Rights Law Journal 19 (1998); Clare Ovey, "The Margin of Appreciation and Article 8 of the Convention," Human Rights Law Journal 19 (1998); Soren C. Prebensen, "The Margin of Appreciation and Articles 9, 10 and 11 of the Convention," Human Rights Law Journal 19 (1998); Urska Prepeluh, "Die Entwicklung der Margin of Appreciation-Doktrin im Hinblick auf die Pressefreiheit," Zeitschrift für ausländisches öffentliches Recht und Völkerrecht 61 (2001); Annette Rupp-Swienty, Die Doktrin von der Margin of Appreciation in der Rechtsprechung des Europäischen Gerichtshofs für Menschenrechte, $1^{\text {st }}$ ed. (Munich: VVF-Verlag, 1999); Jeroen Schokkenbroeck, "The Basis, Nature and Application of the Marginof-Appreciation Doctrine in the Case-law of the European Court of Human Rights," Human Rights Law Journal 19 (1998); Yves Winisdoerffer, "Margin of Appreciation and Article 1 of Protocol Nr. 1," Human Rights Law Journal 19 (1998); Howard C. Yourow, The Margin of Appreciation Doctrine in the Dynamics of European Human Rights Jurisprudence, $1^{\text {st }}$ ed. (Dordrecht: Martinus Nijhoff Publishers, 1996); Howard C. Yourow, "The Margin of Appreciation Doctrine in the Dynamics of the Strasbourg Jurisprudence and the Construction of Europe," Zeitschrift für europarechtliche Studien 1 (1998).

${ }^{5}$ Article 2 ECHR reads as follows: "1. Everyone's right to life shall be protected by law. No one shall be deprived of his life intentionally save in the execution of a sentence of a court following his conviction of a crime for which this penalty is provided by law. 2. Deprivation of life shall not b-e regarded as inflicted in contravention of this article when it results from the use of force which is no more than absolutely necessary: (a) in defence of any person from unlawful violence; (b) in order to effect a lawful arrest or to prevent escape of a person lawfully detained; (c) in action lawfully taken for the purpose of quelling a riot or insurrection."

${ }^{6}$ On this issue cf. also Stefan Kirchner, "Abortion and the Right to Life under Art. 2 of the European Convention on Human Rights"; in: Asifa Begum, ed., Medical Treatment and Law, $1^{\text {st }}$ ed. (India: ICFAI University Press Hyderabad, 2010); Stefan Kirchner, "Abortion and the Right to Life under Art. 2 of the European Convention on Human Rights," IUP Journal of Environment \& Health Care Law 9 (2010). 
direction can be seen in the Court's extensive interpretation of Art. 2 (2) ECHR to the detriment of unborn humans.

To answer the question whether human rights are sufficiently guaranteed under the Convention even in times of emergency we will first look at general rules concerning the restriction of rights under the Convention. We will then move our investigation to Art. $15 \mathrm{ECHR}$ and will then look at some special cases.

\section{GENERAL RULES}

The term "general" rules might be somewhat misleading, but there are unified rules on how at least some of the rights protected by the Convention can be limited by the states parties to the ECHR. This applies in particular to Articles $8-11$ of the Convention, ${ }^{7}$ which contain rules on the limitation of rights in their respective sections $2^{8}$

\subsection{THE SCOPE OF THE RIGHTS UNDER THE CONVENTION}

In order to understand how states can legally limit Convention rights in regular times, one has first to understand the scope of the right in question. ${ }^{9}$ The scope of a right under the Convention is affected when a state organ limits or prohibits the exercise of a right. ${ }^{10}$ Yet, not every minor effect is considered to touch the scope of a right under the ECHR. Rather, the state's measure has to reach a certain degree of intensity. For example Mark E. Villiger, a Swiss law professor who is the Liechtensteinian judge at the European Court of Human Rights, favors a narrow view and only assumes that a certain state behavior affects a right if it is directly aimed at the rights holder, ${ }^{11}$ while the Court favors a wider view, assuming that the scope of a right is affected more easily. ${ }^{12}$ This second view is to be favored since it allows for a wider protection of rights ${ }^{13}$ without being too far-reaching as infringements can be justified more easily according to this model ${ }^{14}$ - if they meet the necessary requirements.

\footnotetext{
7 Anne Peters, Einführung in die Europäische Menschenrechtskonvention, $1^{\text {st }}$ ed. (Munich: Verlag C. H. Beck, 2003), p. 22.

${ }^{8}$ Ibid.

${ }^{9}$ Ibid.

${ }_{10}$ Ibid.

${ }_{11}$ Mark E. Villiger, Handbuch der Europäischen Menschenrechtskonvention, $2^{\text {nd }}$ ed. (Zürich: Schulthess Verlag, 1999), para. 542; cf. also the overview at Anne Peters, supra note 7, p. 22.

${ }_{12}$ Cf. Anne Peters, supra note 7, p. 22.

13 Ibid.

${ }^{14}$ Ibid.
} 


\subsection{LIMITS TO CONVENTUAL RIGHTS}

The question then is how infringements upon human rights can be justified under the Convention. In general, the Convention differentiates between three different ways in which rights can be limited: ${ }^{15}$ Articles 15 to 17 ECHR include general rules, ${ }^{16}$ including states of emergency (Article 15 ECHR), to which we will return in a moment and a prohibition of an abuse of rights guaranteed by the Convention (Article 17 ECHR). In addition, the Convention knows special limitations for specific rights as well as implied limitations for those rights which are not subject to general or special limitations. ${ }^{17}$

\subsubsection{IMPLIED LIMITATIONS}

Such implied limitations are somewhat problematic since they affect rights which, according the wording of the Convention, are not subject to explicit limitations. Yet, since the exercise of one right will often affect the rights of others, some sort of limitation will often be inevitable. At the same time, the idea of a maximum protection of human rights makes it necessary to use this concept sparingly, which explains why the Court has assumed such implied limitations of rights in only a few cases, for example ${ }^{18}$ concerning the prohibition of inhuman or degrading treatment (Article $3 \mathrm{ECHR})^{19}$, the right to marry (Article $12 \mathrm{ECHR}$ ), ${ }^{20}$ the right to education (Article 2 Protocol 1$)^{21}$ as well as the right to vote (Article 3 Protocol 1$)^{22}$ and the right to fair trial, in particular the right to access to a court (Article 6 (1) ECHR) ${ }^{23}$ - a right which the Court itself has problems dealing with, given the large number of new applications it deals with and the significant backlog of cases. ${ }^{24}$ (It is hoped that the new Protocol 14 which will not only allow for

\footnotetext{
${ }^{15}$ Ibid.

16 Ibid.

17 Ibid.

18 The following examples are taken from Anne Peters, supra note 7, p. 26.

19 Ibid., p. 44.

${ }^{20}$ Goodwin v. United Kingdom, ECtHR Judgment of 11 July 2002, para. 99; I. v. United Kingdom, ECtHR Judgment of 11 July 2002, para. 79.

${ }_{21}$ Kjeldsen, Busk Madsen and Pedersen v. Denmark, ECtHR Judgment of 7 December 1976, para. 53.

22 Podkolzina v. Lithuania, ECtHR Judgment of 9 April 2002, para. 34.

${ }^{23}$ Fürst Hans-Adam II. von und zu Liechtenstein v. Germany, ECtHR Judgment of 12 July 2001, para. 44. A recent case concerning access to the court was decided by the Grand Chamber on 23 March 2010 in Cudak v. Lithuania.

${ }^{24}$ The problem of the case load of the Court cf. Mark W. Janis, Richard S. Kay, and Anthony W.Bradley, European Human Rights Law - Text and Materials, $3^{\text {rd }}$ ed. (Oxford: Oxford University Press, 2008), p. 878 et seq. and p. 884 et seq.; Luzius Wildhaber, The European Court of Human Rights 1998-2006: History, Achievements, Reform, $1^{\text {st }}$ ed. (Kehl am Rhein: Verlag N. P. Engel, 2006), p. 136 et seq. On the concept of Pilot Judgments cf. also Report of the Group of Wise Persons to the Committee of Ministers, Council of Europe, CM (2006) 2003, 15 November 2006. But see also Marie-Bénédicte Dembour, "'Finishing Off' Cases: The Radical Solution to the Problem of the Expanding ECHR Caseload," European Human Rights Law Review 5 (2002): 622. On the responsibility of the Court to ensure its ability to function by weeding out cases cf. Amnesty International, "NGO Comments on the Group of Wise Persons," Interim Report 3 (2006). Simply increasing the number of judges from one per member state to two, while at first sight a simple measure, is thought not only to be opposed by states parties to the
} 
accession of the European Union to the Convention ${ }^{25}$ but, probably more important, will establish a new filtering system which will allow the Court to disallow cases which are very similar to cases which have already been decided against the same state party and which will require that the claimant proves a significant disadvantage, which could signal a fundamental shift in the role of the Court in protecting human rights in Europe.) The fact that the ECtHR has not yet had the opportunity to examine implied limitations in more detail also means that there are no unified rules concerning implied limitations. ${ }^{26}$ Yet some generalized assumptions can already be made: What is required to limit rights based on an unwritten notion of implied rights is that the limitation serves a legitimate aim, ${ }^{27}$ that the limitation itself is proportionate ${ }^{28}$ and based on law. ${ }^{29}$ This already follows a fortiori from the fact that this is also required in cases in which the Convention itself already allows for limitations. ${ }^{30}$

\subsubsection{ARTICLE-SPECIFIC LIMITATIONS}

\section{In accordance with the law}

That a limitation has to be based on (domestic) law is a key rule which has been developed by the Court with regard to special, or article-specific, limitations expressly allowed by the Convention. ${ }^{31}$ As the Court stated in Herczegfalvy $v$. Austria, "the expression "in accordance with the law" requires firstly that the impugned measure should have some basis in national law; it also refers to the quality of the law in question, requiring that it should be accessible to the person

Convention for financial reasons (Mark W. Janis, Richard S. Kay, and Anthony W.Bradley, supra this note, p. 885), but would also make it difficult to achieve the collegiality necessary to achieve a truly coherent jurisprudence of the Strasbourg Court (Paul Mahoney, "New Challenges for the European Court of Human Rights Resulting from the Expanding Case Load and Membership," Penn State International Law Review 21 (2002): 106).

${ }^{25}$ On the possibility of an accession of the European Union to the ECHR from a Convention perspective cf. Mark W. Janis, Richard S. Kay, and Anthony W.Bradley, supra note 24, p. 885 et seq.; Hans Christian Krüger, "Reflections Concerning Accession of the European Communities to the European Convention on Human Rights," Penn State International Law Review 21 (2002): 92 et seq.; see also more generally Albert Bleckmann, Die Bindung der Europäischen Gemeinschaft an die Europäische Menschenrechtskonvention, $1^{\text {st }}$ ed. (Cologne: Carl Heymanns Verlag, 1986); Regine Gerards, Die Europäische Menschenrechtskonvention im Konstitutionalisierungsprozess einer gemeineuropäischen Rechtsordnung, $1^{\text {st }}$ ed. (Frankfurt: Verlag Peter Lang, 2007); as well as Susanne Stock, Der Beitritt der Europäischen Union zur Europäischen Menschenrechtskonvention als gemischtes Abkommen?, $1^{\text {st }}$ ed. (Hamburg: Verlag Dr. Kovac, 2010); Sebastian Winkler, Der Beitritt der Europäischen Gemeinschaften zur Europäischen Menschenrechtskonvention, $1^{\text {st }}$ ed. (Baden Baden: Nomos, 2000); Kyra Strasser. Grundrechtsschutz in Europa und der Beitritt der Euopäischen Union zur Europäischen Menschenrechtskonvention, $1^{\text {st }}$ ed. (Frankfurt am Main: Verlag Peter Lang, 2001); Julia Molthagen, Das Verhältnis der EU-Grundrechte zur EMRK - Eine Untersuchung unter besonderer Berücksichtigung der Charta der Grundrechte der EU, Dissertation (Hamburg, 2003) //

http://www.sub.uni-hamburg.de/opus/volltexte/2003/967/pdf/dissertation.pdf (accessed May 28, 2010).

${ }^{26}$ Anne Peters, supra note 7, p. 27.

27 Ibid.

${ }^{28}$ Ibid.

${ }^{29}$ Ibid.

${ }^{30}$ Ibid.

${ }^{31}$ Sunday Times v. United Kingdom, ECtHR Judgment of 26 April 1979, paras. 46-53. 
concerned, who must moreover be able to foresee its consequences for him, and compatible with the rule of law (see, inter alia, the Kruslin and Huvig v. France judgments of 24 April 1990, Series A no. 176-A, p. 20, paras. 26-27, and no. 176$B$, p. 52, paras. 25-26)." ${ }^{132}$ Such legal limitations are permissible only in the cases outlined in the section 2 of the Article in question. ${ }^{33}$

\section{Necessary in a democratic society}

These cases include measures which are necessary in a democratic society, which means that there has to be a pressing social need for the state to take the action in question which limits rights under the Convention. ${ }^{34}$ The severity of the measures must not be disproportionate to the aim of the measure, ${ }^{35}$ and, even more, the Court "must determine whether the interference in issue was proportionate to the legitimate aims pursued and whether the reasons adduced by the national authorities to justify it are relevant and sufficient. ${ }^{\prime \prime 6}$

\section{The Margin of Appreciation}

Nevertheless, the Court respects the sovereignty of the states' parties ${ }^{37}$ by granting them a large margin of appreciation concerning both the conditions for limiting European Convention rights. ${ }^{38}$ This margin of appreciation is said to be even wider when national interests are at stake which dominate over the interests of an individual. ${ }^{39}$ This approach is problematic since human rights law to a large extent developed for the purpose of protecting individuals against the power of the majority.

\section{Enumerated Cases allowing for Limitations of Human Rights}

It is particularly important that limitations of human rights outside a state of emergency are only possible in a small number of cases, specifically, in those cases envisaged by section 2 of the relevant norm of the Convention, for example for the protection of national security, the prevention of crime, the protection of the rights of others or of public health. ${ }^{40}$

\footnotetext{
32 Herczegfalvy v. Austria, ECtHR Judgment of 24 September 1992, para. 88 [italics added].

${ }^{33}$ Anne Peters, supra note 7, p. 24.

${ }^{34}$ Sener v. Turkey, ECtHR Judgment of 18 July 2000, para. 39.

35 Anne Peters, supra note 7, p. 24.

${ }^{36}$ Sener v. Turkey, supra note 34, para. 39; also quoted by Anne Peters, supra note 7, p. 24 et seq.

${ }^{37}$ Cf. Anne Peters, supra note 7, p. 25.

38 Ibid.

${ }^{39}$ Cf. ibid., p. 25 et seq.

${ }^{40}$ Ibid., p. 24.
} 


\section{ARTICLE 15 ECHR}

In times of emergency, though, this possibility might not be enough to deal with pressing problems. Article 15 ECHR therefore allows states' parties to the Convention to derogate from their obligations under the Convention, albeit not concerning all rights under the ECHR. ${ }^{41}$

Derogation means that the Convention as a whole is not applicable to the subject matter covered by the derogation. ${ }^{42}$ Derogations differ from reservations ${ }^{43}$ in that they exclude the applicability of the ECHR as a whole under special circumstances while reservations ${ }^{44}$ under Art. 57 ECHR refer to particular provisions of the Convention. While derogations are general with regard to the subject matter and specific with regard to the circumstances, reservations are specific with regard to the subject matter and may not, by law, be general in nature. ${ }^{45}$

Derogations might have been rare, but nevertheless a critical part of the European Human Rights System in that they create an option for states' parties to the Convention to severely limit the protection of human rights enjoyed vis-à-vis the state which feels compelled to derogate from the ECHR. The Convention organs have approached derogation cases by first examining the substantive complaint before approaching the issue of whether the right in question was covered by the derogation. ${ }^{46}$

\subsection{WORDING OF THE NORM}

Article 15 of the European Convention of Human Rights reads as follows:

"1. In time of war or other public emergency threatening the life of the nation any High Contraction Party may take measures derogating from its obligations under this Convention to the extent strictly required by the exigencies of the situation, provided that such measures are not inconsistent with its other obligations under international law.

2. No derogation from Article 2, except in respect of deaths resulting from lawful acts of war, or from Articles 3,4 (paragraph 1) and 7 shall be made under this provision.

\footnotetext{
${ }^{41}$ Karen Reid, A Practitioner's Guide to the European Convention on Human Rights. $3^{\text {rd }}$ ed. (London: Sweet \& Maxwell, 2007), p. 262.

${ }^{42}$ Christoph Grabenwarter, Europäisches Menschenrechtskonvention, $3^{\text {rd }}$ ed. (Munich: Verlag C. H. Beck, 2008), p. 11.

${ }^{43}$ On reservations under international law in general cf. Articles 19 et seq. of the Vienna Convention on the Law of Treaties; on reservations under the ECHR cf. J. Abraham Frowein, "Reservations to the European Convention on Human Rights"; in: Franz Matscher and Herbert Petzold, supra note 2.

44 On reservations under Art. 57 ECHR cf. Clare Ovey and Robin C. A. White, Jacobs \& White: The European Convention on Human Rights, $4^{\text {th }}$ ed. (Oxford: Oxford University Press, 2006), p. 451 et seq.

${ }^{45}$ In fact, Art. 57 (1) sentence 2 ECHR expressly prohibits reservations of a general character.

${ }^{46}$ Karen Reid, supra note 41 , p. 262.
} 
3. Any High Contracting Party availing itself of this right of derogation shall keep the Secretary-General of the Council of Europe fully informed of the measures which it has taken and the reasons therefore. It shall also inform the SecretaryGeneral of the Council of Europe when such measures have ceased to operate and the provisions of the Convention are again being fully executed."

\subsection{EXAMPLES}

In the past, Greece, Ireland, Turkey, the United Kingdom, Albania and France have issued derogations, primarily for the purpose of limiting judicial guarantees under Articles 5 and 6 ECHR. ${ }^{47}$ Until February 2001, the United Kingdom had a derogation concerning the situation in Northern Ireland; likewise, Turkey had derogations concerning PKK activities in the south-eastern part of the country. ${ }^{48}$ Because of Art. 53 ECHR, Art. 15 ECHR is more important for those states which lack a national human rights standard which is comparable to the standard of the Convention. ${ }^{49}$ After 9/11, the United Kingdom claimed a derogation concerning the war on terror. ${ }^{50}$ This derogation was criticized as being disproportionate ${ }^{51}$ and has since been withdrawn.

\subsection{SUBSTANTIVE REQUIREMENTS}

Derogations are possible in times of war or in case of other emergencies:

\subsubsection{WAR}

So far, no derogation has yet been made with regard to a state of war. ${ }^{52}$ War, in the context of Art. 15 ECHR, refers to war between states. ${ }^{53}$ Thus far the Convention reflects the time during which it was drafted and does not yet take into

${ }^{47}$ Christoph Grabenwarter, supra note 42, p. 11. Cf. Heinz-Eberhard Kitz, Die Notstandsklausel des Art. 15 der Europäischen Menschenrechtskonvention, $1^{\text {st }}$ ed. (Berlin: Duncker \& Humblot, 1982), p. 96 et seq.

${ }^{48}$ Karen Reid, supra note 41 , p. 262, there fn. 2. In case of geographically limited derogations (which have often been used by Turkey during the conflict with the Partiya Karkerên Kurdistan (PKK), cf. Clare Ovey and Robin C. A. White, supra note 44, p. 443, there fn. 23) the state cannot rely on the derogation concerning other parts of the country, even in case of a thematic nexus between the derogation and the measure in question (Karen Reid, supra note 41, p. 263; Clare Ovey and Robin C. A. White, supra note 44, p. 444 et seq.; Sakik and others v. Turkey, ECtHR Judgment of 26 November 1997, paras 26 et seq.; see also Adulsamet Yaman v. Turkey, ECtHR Judgment of 2 November 2004, paras 68 et seq.

${ }^{49}$ Christoph Grabenwarter, supra note 42, p. 11.

${ }^{50}$ Karen Reid, supra note 41, p. 262. On this derogation cf. A. and others. $v$. United Kingdom, ECtHR Judgement of 19 February 2009; and Heike" Krieger, "Notstand": at margin no. 2; in: Rainer Grote and Thilo Marauhn, eds., Konkordanzkommentar zum europäischen und deutschen Grundrechtsschutz (Tübingen: Mohr Siebeck, 2006).

${ }^{51}$ Christoph Grabenwarter, supra note 42, p. 11; Christoph Grabenwarter, "Right to a Fair Trial and Terrorism"; Société Française pour la Droit International, ed., Les nouvelles ménaces contre la paix et la sécurité internationales (2004). See also A. and others $v$. Secretary of State for the Home Department, House of Lords; in: Europäische Grundrechtezeitschrift 32 (2005): 488.

52 Karen Reid, supra note 41, p. 263. 
account new developments in the law of armed conflict. But this is not necessary since war is simply one case of the more general aspect of the state of emergency and non-international conflicts ${ }^{54}$ are also covered by Art. 15 ECHR.

\subsubsection{PUBLIC EMERGENCY THREATENING THE LIFE OF THE NATION}

The state of emergency for which a derogation can be permissible requires a threat to the life of the nation. This means that the situation has to affect the population as a whole ${ }^{55}$ and that it has to constitute a threat to the organized life of the community. ${ }^{56}$ The term "life of the nation" in this context does not necessarily mean "existence of the state" or "existence of the people" but is understood much wider, in the sense of the "way of life" which is protected as well.

In Lawless v. Ireland, the Court required for the applicability of Art. 15 (1) ECHR that there exists "an exceptional situation of crisis or emergency which affects the whole population and constitutes a threat to the organized life of the community of which the State is composed. ${ }^{157}$

In determining whether such a state of emergency which threatens the life of the nation, ${ }^{58}$ states enjoy a wide but not unlimited margin of appreciation because, in line with the idea of subsidiarity, the national authorities are thought to be closer to the reality on the ground and therefore better able to determine whether an emergency exists and how to deal with them than international judges in Strasbourg. ${ }^{59}$ The question whether the state has exceeded the limits of the margin of appreciation is to be examined as part of the question whether the derogation has been strictly required by the exigencies of the situation. ${ }^{60}$ It is up to the states' parties to the Convention, which are responsible for the life of the nation, ${ }^{61}$ "to determine whether that life is threatened by a 'public emergency' and, if so, how far it is necessary to go in attempting to overcome the emergency." ${ }^{162}$

\footnotetext{
53 Christoph Grabenwarter, supra note 42, p. 11.

54 This is evidenced by the fact that also a war has to threaten the life of the nation (Christoph Grabenwarter, supra note 42 , p. 11) in order to allow a state party to the Convention to derogate from the ECHR. For example the war against Serbia did not provide a sufficient threat to the life of the nation to allow those NATO member states which are also parties to the ECHR to derogate from the Convention.

${ }^{55}$ Karen Reid, supra note 41 , p. 263.

${ }^{56}$ Ibid.; Lawless v. Ireland, ECtHR Judgment of 1 July 1961, para. 28.

57 Ibid.; Clare Ovey and Robin C. A. White, supra note 44, p. 443.

${ }^{58}$ Karen Reid, supra note 41, p. 263.

${ }^{59}$ Ibid.

60 Ibid.; Ireland v. United Kingdom, supra note 4, para. 207; Lawless v. Ireland, supra note 56, para. 28.

${ }_{61}$ Clare Ovey and Robin C. A. White, supra note 44, p. 445; Aksoy v. Turkey, ECtHR Judgment of 18 December 1996, para 68.

62 Ibid.
} 


\subsubsection{MEASURES STRICTLY REQUIRED BY THE EXIGENCIES OF THE}

\section{SITUATION}

The measures taken by the national authorities during the state of emergency have to be strictly required by the situation at hand. This is the case if the emergency cannot be dealt with in any other manner. Grabenwarter requires that derogations, like limitations of Conventual rights in normal times, are proportionate to the threat they are meant to address. ${ }^{63}$ Yet, the use of the proportionality requirement in this context is not helpful. It is dogmatically clearer to examine the necessity of the derogation (which Grabenwarter in fact does immediately after his abovementioned remark concerning the proportionality by focusing his explanation on the issue of necessity ${ }^{64}$ ). In Lawless v. Ireland ${ }^{65}$ and Ireland v. United Kingdom ${ }^{66}$ the Court accepted that the threat posed by terrorism could not have been dealt with adequately under normal laws. ${ }^{67}$ This is what makes the special situation exceptional: the need for exceptional laws rather than laws which could have been passed during the normal course of events because "the normal measures permitted by the Convention are plainly inadequate to deal with the situation. ${ }^{\prime 68}$

In its investigation the Court will not only look at the measure as such but also at its intensity, which is why it adjudicated in favor of the claimant in Aksoy $v$. Turkey ${ }^{69}$ based on the fact that it considered the 30-day detention period at stake in that case ${ }^{70}$ to be longer than necessary. ${ }^{71}$ What makes the Court's work in this regard effective is the Court's holistic approach to the issue, taking into account the entire situation, including "the safeguards which the State puts in place to compensate for suspension of the rights required by the Convention provision in respect of which the derogation is filed, ${ }^{\prime 72}$ i.e. the protection of individuals affected by the special measures ${ }^{73}$ or the degree of parliamentary supervision ${ }^{74}$ or the risk of an abuse associated with the emergency measures. ${ }^{75}$ The latter can be limited by a timely end to the extraordinary measures (which is already implicitly required by Art. 15 (3) sentence 2 ECHR) while at the same time a change in the facts on the ground can necessitate an end to the measures and the state will have to end the

\footnotetext{
${ }^{63}$ Christoph Grabenwarter, supra note 42, p. 12.

64 Ibid.

65 Lawless v. Ireland, supra note 56.

${ }^{66}$ Ireland $v$. United Kingdom, supra note 4.

67 Karen Reid, supra note 41, p. 264.

68 Clare Ovey and Robin C. A. White, supra note 44, p. 443.

69 Aksoy v. Turkey, supra note 61.

70 The law allowed for 30 days of detention while the applicant was only held for 14 days (Karen Reid, supra note 41, p. 264 , there fn. 11 ).

71 Karen Reid, supra note 41, p. 264.

72 Clare Ovey and Robin C. A. White, supra note 44, p. 447. See also Brannigan and McBride v. United Kingdom, ECtHR Judgment of 26 May 1993; and Aksoy v. Turkey, supra note 61.

73 Karen Reid, supra note 41, p. 266.

74 Ibid., p. 265.

${ }^{75}$ Ibid., p. 264
} 
derogation when the situation has been changed so far as it is no longer necessary to deal with the situation. ${ }^{76}$

Finally, the Court expects that the authorities will strive to improve the human rights situation even during the continuation of the emergency. This was the case "[i]n Ireland v. UK, where the safeguards were less apparent or effective than in Lawless [v. Ireland]". ${ }^{77}$ In Ireland v. UK "the Court placed emphasis on the fact that the authorities responded to the situation by evolving towards protecting individual liberties in the measures". ${ }^{78}$

The purpose of Article 15 ECHR "is to guarantee the continuing existence of the democratic rule of law" $^{\prime 79}$ (in so far the ECHR differs from the more rightscentered approach of the derogation clause (Article 4) of the International Covenant on Civil and Political rights which is to be interpreted in so far as "the restoration of a state of normalcy where full respect for the Covenant can again be secured must be the predominant objective of a State Party derogating from the Covenant". ${ }^{80}$ The ECHR is significantly more holistic in that it accepts that the enjoyment of rights is only possible in a situation in which the rule of law is guaranteed for the present as well as for the future. Unlike the Covenant, which is a global instrument and at the time of its creation was more inspiration than reality, the European Convention on Human Rights is firmly rooted in the experiences of the continent, which certainly adds to its success and the level of compliance.

\subsubsection{COMPATIBILITY WITH THE STATE PARTY'S OTHER OBLIGATIONS UNDER INTERNATIONAL LAW}

In addition, derogations are only permissible if they do not violate the state's other obligations under international law. Article 4 ICCPR can pose a problem in this respect as well. Many rights are covered both by the ICCPR and the ECHR, which makes it necessary for a state which is a party to both human rights instruments to declare derogations under both Conventions but unlike Article 15 ECHR, Article 4 ICCPR requires that derogations are published. A derogation which has not been published might be permissible under the ECHR but would be incompatible with

\footnotetext{
${ }^{76}$ On the changing situation in Northern Ireland during the peace process see Karen Reid, supra note 41 , p. 265.

77 Ibid.

78 Ibid.

${ }^{79}$ Cees Flinterman, "Derogation from the Rights and Freedoms in Case of a Public Emergency": 1055; in: Pieter van Dijk, Fried van Hoof, Arjen van Rijn, and Leo Zwaak, eds., Theory and Practice of the European Convention on Human Rights, $4^{\text {th }}$ ed. (Antwerpen, Oxford: Intersentia, 2006).

80 General Comment No. 29, States of Emergency (Article 4), Human Rights Committee, CCPR/C/21/Rev.1/Add.11, 31 August 2001, p. 2; also quoted in Cees Flinterman, supra note 79, p. 1055 , there fn. 5 .
} 
Article 4 ICCPR and by virtue of this incompatibility also not allowed under the European Convention on Human Rights. ${ }^{81}$

\subsection{THE PROCEDURE OF DEROGATION}

In submitting the derogation, the state in question is bound by Article 15 (3) ECHR. ${ }^{82}$ Art. 15 (3) ECHR requires the state to submit the derogation to the Secretary General of the Council of Europe. ${ }^{83}$

\subsubsection{NOTIFICATION}

The state which claims a derogation has to inform the Secretary General of the Council of Europe of the reasons for the derogation as well as of the measures which have been taken in this context. ${ }^{84}$ Despite the lack of expressed sanctions, ${ }^{85}$ this notification requirement is constitutive for the legality of the derogation. ${ }^{86}$ Art. 15 (3) ECHR includes the obligation on the part of the state to name the laws in question $^{87}$ and to provide the Secretary General of the Council of Europe with the relevant legal texts. ${ }^{88}$ For example, in the derogation leading up to the Lawless Case, the Irish government provided the Secretary General of the Council of Europe not only with the proclamation of the derogation but also with the relevant codified laws. ${ }^{89}$ On the other hand, the Court held in Aksoy v. Turkey ${ }^{90}$ that the Turkish notification lacks the necessary degree of specification in that it did not name the measures which had been taken under the derogation. ${ }^{91}$

The notification does not have to be immediate. Rather, as the Court called it in Lawless, ${ }^{92}$ it has to be "without delay". ${ }^{93}$ The Court has been very generous in allowing states a certain degree of flexibility in this regard, allowing for a twelve day interval between the adoption of measures under national law and the subsequent notification ${ }^{94}$ in Lawless $v$. Ireland ${ }^{95}$ and even four months ${ }^{96}$ in the Greek case, ${ }^{97}$ (although it has to be noted that there were special circumstances

${ }^{81}$ Cf. also Karen Reid, supra note 41, p. 266.

${ }^{82}$ Christoph Grabenwarter, supra note 42, p. 13.

83 Ibid.

${ }^{84}$ Karen Reid, supra note 41, p. 262.

85 Clare Ovey and Robin C. A. White, supra note 44, p. 450.

${ }^{86}$ Christoph Grabenwarter, supra note 42, p. 13.

${ }^{87}$ Karen Reid, supra note 41, p. 262.

${ }^{88}$ Ibid.

${ }^{89}$ Ibid., there fn. 3.

${ }^{90}$ Aksoy v. Turkey, supra note 61.

${ }^{91}$ Karen Reid, supra note 41, p. 263.

92 Lawless v. Ireland, supra note 56.

${ }_{93}$ Ibid., para. 62; Clare Ovey and Robin C. A. White, supra note 44, p. 449.

${ }^{94}$ Ibid.

${ }^{95}$ Lawless v. Ireland, supra note 56.

${ }^{96}$ Clare Ovey and Robin C. A. White, supra note 44, p. 449.

97 Greek Case, EComHR Report, Yearbook of the European Court of Human Rights 12 (1969): 1 et seq.; Committee of Ministers Resolution DH (70) 1, 15 April 1970 // 
following the Greek coup d'etat on 21 April 1967, ${ }^{98}$ which of course cannot justify the lack of compliance with the ECHR). Therefore, although "notification under Article 15 (3) [ECHR] may have a very limited retroactive effect [and no specific] time limit is laid down for notifications, [...] the Court appeared to consider in the Lawless case $\left[{ }^{99}\right]$ that communication without delay is an element in the sufficiency of information required by"100 Article 15 (3) ECHR.

\subsubsection{DOMESTIC PROCLAMATION}

It is important to note that there is no requirement on the part of the state to publicly announce the derogation domestically. ${ }^{101}$ This obligation of the state is towards the Secretary General of the Council of Europe, not towards the citizens. While compatible with the clear wording of the Convention, such a narrow interpretation is unfortunate in that it can limit the effectiveness of the Convention. In fact the lack of an obligation to publicize derogations undermines the rule of law, which Article 15 is supposed to safeguard in the long run, by allowing states to take extraordinary measures for the purpose of protecting the functioning of the state in the long term, in that it allows situations in which potential applicants cannot know the legal situation including the rights they can claim in Strasbourg.

Brannigan and McBride ${ }^{102}$ has been interpreted by some authors to require some form of official promulgation of the derogation, ${ }^{103}$ but there is "no direct authority on this issue". ${ }^{104}$ Nevertheless, due to the Court's holistic approach it is not too far-fetched to assume that "a [s]tate which had not made any formal announcements within the legal order might find itself facing greater difficulty in proving the existence of a public emergency before the Court." ${ }^{105}$

http://www.ena.lu/resolution dh 70 committee ministers council europe 15 april 1970$020005255 . \mathrm{html}$ (accessed May 28, 2010).

${ }_{98}$ After the coup, Greece would eventually leave the Council of Europe only to return again later. In so far and as it has been proven by the fact that the Eastern European states quickly joined the Council after the end of the Cold War, membership in the Council has become a yardstick for measuring the development of European states and even the Vatican, although not a member, participates indirectly in that the Holy See has observer status at the CoE. Currently this leaves Belarus and Kazahkstan the odd ones out (see already footnote 3). The yardstick role of the ECHR for EU candidate countries might also explain the continued interest in forging a closer connection between the EU and the COE despite the emergence of a specific EU human rights regime.

${ }_{99}$ Lawless $v$. Ireland, supra note 56 , paras. 42 et seq.

${ }^{100}$ Clare Ovey and Robin C. A. White, supra note 44, p. 449.

101 Karen Reid, supra note 41, p. 263; Lawless v. Ireland, supra note 56, para 47.

102 Brannigan and McBride $v$. United Kingdom, supra note 72.

${ }^{103}$ Cf. Clare Ovey and Robin C. A. White, supra note 44, p. 448.

${ }^{104}$ Ibid.

105 Ibid., pp. 448 et seq. 


\subsection{NON-DEROGABLE RIGHTS}

Certain rights under the Convention are non-derogable. According to Article 15 (2) ECHR, these are the right to life (Article 2 ECHR, except in respect of deaths resulting from lawful acts of war), the prohibition of torture (Art. 3 ECHR), the prohibition of slavery (Art. 4 (1) ECHR) and the right not to be punished without a legal basis (Art. $7 \mathrm{ECHR}$, nulla poena sine lege).

The right to freedom of thought, conscience and religion under Art. $9 \mathrm{ECHR}$ is not expressly mentioned in Art. 15 (2) ECHR, yet in practice it is non-derogable for those states parties to the Convention which are also parties to the ICCPR: the legality of a derogation under Art. 15 ECHR requires the compatibility of the derogation with the other international obligations of the state in question and the ICCPR does not allow for a derogation of the freedom of thought, conscience and religion due to Art. 4 (2) ICCPR. ${ }^{106}$

The non-derogability of the right to life (Art. 2 ECHR) during a state of emergency is not absolute in that derogations are permitted with regard to killings in times of war which are a result of "lawful acts of war" (Art. 15 (2) ECHR). ${ }^{107}$ Here it is not just the derogation which has to be compatible with the other obligations of the state in question under international law but the action taken on the basis of this derogation has to be lawful under the obligations under international humanitarian law incumbent upon the derogating state.

\section{SPECIAL CASES}

As the first decade of the new century is characterized by a general sense of crisis, ${ }^{108}$ including fears of global terrorism, diseases and most recently economic crisis, some special cases deserve particular attention since they are more likely to prompt states to derogate from their international human rights obligations:

\subsection{TERRORISM}

The purpose of Article $15 \mathrm{ECHR}$ is to guarantee the rule of law in the long term - while imposing some limitations on states on how to achieve this goal. For example, while this goal might have been on the minds of Turkish authorities who were fighting Kurdish separatists who posed a threat to the integrity of the state, it already becomes questionable if the general threat of terrorism after 9/11 would

\footnotetext{
106 Christoph Grabenwarter, supra note 42, p. 12.

107 See also Clare Ovey and Robin C. A. White, supra note 44, p. 441.

108 Cf. "Strategies for Solving Global Crises - The Financial Crisis and Beyond," Göttingen Journal of International Law 2 (2010) [special issue] //
} 
have been sufficient, had it not been for specific ideology of Al Qaida which seeks to subjugate non-Muslim areas under their interpretation of Islam. The derogations made by Britain in the context of the conflict in Ulster on the other hand were incompatible with the purpose of Article 15 ECHR since, unlike in Turkey, Britain had occupied Ulster, making a stronger case for self-determination in Ulster than in Eastern Anatolia. Yet, in both situations the right of the Kurdish and Irish people to self-determination has not received the necessary attention. The Right to selfdetermination is an accepted right of peoples under international law and needs to be taken into account in the context of Article 15 of the Convention just like any other international obligation of the state which wishes to derogate from the Convention. As follows from the Quebec precedent, ${ }^{109}$ the right to selfdetermination does not have to lead to independence, making the case for derogation harder in instances in which regional secession movements resort to armed force.

Neither the IRA nor the PKK seriously challenged the existence of respectively the United Kingdom and the Turkish Republic as such. The same applied to ETA with regard to Spain and France but the situation is different when it comes to Al Qaida. Although Al Qaida might not have the local infrastructure which had been enjoyed IRA, ETA and PKK, nor does the conflict in Europe (yet) reach the intensity of the aforementioned secessionist conflicts, but Al Qaida's plans, if realized, would have more far-reaching consequences than the plans by any of the three groups mentioned. Yet, the intensity of the conflict between this groups and the states from which they wish to secede and the significant loss of life associated with the conflict already crossed the threshold of the threat to the organized life of the community ${ }^{110}$ and hence to the life of the nation. The states' responsibility to protect the nation necessitates the wide margin of appreciation enjoyed by states in this respect.

The way the norm has been phrased, placing threats to the life of the nation in the context of war, makes it easy to think that only violence-related threats to the life of the nation could be covered by Article 15 ECHR. This is by no means the case.

http://gojil.uni-goettingen.de/joomla/index.php?option=com_wrapper\&view=wrapper\&Itemid=71 (accessed May 14, 2010).

${ }_{109}$ Reference re Secession of Quebec, Supreme Court (Canada) Decision of 30 September 1996, [1998] 2 S.C.R. 217.

${ }^{110}$ Karen Reid, supra note 41, p. 263; Lawless v. Ireland, supra note 56, para. 28. 


\subsection{PUBLIC HEALTH}

In recent years, several highly publicized health threats such as mad cow disease and its human variant, Creutzfeld-Jacob, the avian flu or more recently the swine flu have lead states to take measures aimed at reducing the risk associated with such diseases. For example, it is conceivable that the risks posed to public health by a particularly risky behavior or a transmittable disease can amount to a situation which threatens the life of the nation and which requires special measures which would run afoul of the Convention, would the state not derogate from it. In fact, the states have an obligation to take the necessary measures to protect the population against such risks because the states' duty to protect inherent in the Convention also applies to public health. If the situation is of sufficient gravity and no ordinary means are available which would produce the desired result, the state might even be obliged to derogate from the Convention for the sake of protecting the life of the nation. The omission on the part of states to take extraordinary measures in this respect might in itself become problematic under the Convention.

\section{CONCLUSIONS}

Any derogation includes the risk of abuse. Nevertheless, the ECHR grants states' parties a rather wide margin of appreciation in determining whether there is a situation which amounts to an emergency within the meaning of Art. 15 ECHR as well as concerning the response which the state in question deems necessary to deal effectively with the situation. At the same time, we can conclude that the Convention also contains a corrective in that it requires that the measures taken by the state to deal with the emergency have to pass a test of necessity and the holistic approach shown by the Court has so far served well to strike a balance between giving states the freedom to take the necessary measures and protecting human rights. As the Human Rights Committee has already held with regard to the ICCPR's derogation clause, states which derogate their international human rights obligations have to strive first and foremost to restore the normal status in which the international human rights instrument in question can be fully applied again. ${ }^{111}$

It has to be kept in mind, though, that these findings are based on the relative stability in the states' parties to the Convention. At the time of writing, the global financial crisis had affected some states severely to the point that governments fell but without too severe effects on the states as such and the basic premise of relative stability remains intact. Of course, there is no guarantee that this will continue to be the case. While none of the situations which so far have

${ }^{111}$ General Comment No. 29, States of Emergency (Article 4), supra note 80, p. 2. 
been brought to the attention of the Court had led to a complete breakdown of state functions, it is such a breakdown which could push the Court's construction of Art. 15 ECHR off balance. Under the assumption that the current overall situation is here to stay, we can conclude that, despite some shortcomings such as the lack of publicity, through its holistic approach the Court manages to fulfil its supervisory role in a manner sufficient to strike a balance between safeguarding human rights for all in the long run and the human rights of some in concrete circumstances.

\section{BIBLIOGRAPHY}

1. Amnesty International. "NGO Comments on the Group of Wise Persons." Interim Report 3 (2006).

2. Bleckmann, Albert. Die Bindung der Europäischen Gemeinschaft an die Europäische Menschenrechtskonvention [Obligations of the European Community under the European Convention on Human Rights]. $1^{\text {st }}$ ed. Cologne: Carl Heymanns Verlag, 1986.

3. Brems, Eva. "The Margin of Appreciation Doctrine in the Case-law of the European Court of Human Rights." Zeitschrift für ausländisches öffentliches Recht und Völkerrecht [Heidelberg Journal of International Law] 56 (1996): 240 et seq.

4. Callewaert, Johan. "Is there a Margin of Appreciation in the Application of Articles 2, 3 and 4 of the Convention?" Human Rights Law Journal 19 (1998): 6 et seq.

5. Dembour, Marie-Bénédicte. "'Finishing Off' Cases: The Radical Solution to the Problem of the Expanding ECHR Caseload." European Human Rights Law Review 5 (2002): 604 et seq.

6. Flinterman, Cees. "Derogation from the Rights and Freedoms in Case of a Public Emergency": 1053 et seq. In: Pieter van Dijk, Fried van Hoof, Arjen van Rijn, and Leo Zwaak, eds. Theory and Practice of the European Convention on Human Rights. $4^{\text {th }}$ ed. Antwerpen, Oxford: Intersentia, 2006.

7. Frowein, J. Abraham. "Reservations to the European Convention on Human Rights": 193 et seq. In: Franz Matscher and Herbert Petzold, eds. Protecting Human Rights: the European dimension: studies in honour of Gérard J. Wiarda. $2^{\text {nd }}$ ed. Cologne: Carl Heymanns Verlag, 1990.

8. Gerards, Regine. Die Europäische Menschenrechtskonvention im Konstitutionalisierungsprozess einer gemeineuropäischen Rechtsordnung [The European Convention on Human Rights in the Process of the Constitutionalisation of a common European legal order]. $1^{\text {st }}$ ed. Frankfurt: Verlag Peter Lang, 2007. 
9. Grabenwarter, Christoph. Europäisches Menschenrechtskonvention [European Convention on Human Rights]. $3^{\text {rd }}$ ed. Munich: Verlag C. H. Beck, 2008.

10. Grabenwarter, Christoph. "Right to a Fair Trial and Terrorism": 211 et seq. In: Société Française pour la Droit International, ed. Les nouvelles ménaces contre la paix et la sécurité internationales [The new threats against international peace and security] (2004).

11. Greer, Steven. The European Convention on Human Rights: achievements, problems and prospects. $1^{\text {st }}$ ed. Cambridge: Cambridge University Press, 2006.

12. Grote, Rainer, and Thilo Marauhn, eds. Konkordanzkommentar zum europäischen und deutschen Grundrechtsschutz [Concordance commentary on European and German Protection of Basic Rights]. Tübingen: Mohr Siebeck, 2006.

13. Harris, David J., Michael O'Boyle, Edward Bates, and Carla Buckley. Harris, O'Boyle \& Warbrick Law of the European Convention on Human Rights. $2^{\text {nd }}$ ed. Oxford: Oxford University Press, 2009.

14. Hutchinson, Michael R. "The Margin of Appreciation Doctrine in the European Court of Human Rights." International and Comparative Law Quarterly 48 (1999): 638 et seq.

15. Janis, Mark W., Richard S. Kay, and Anthony W. Bradley. European Human Rights Law - Text and Materials. $3^{\text {rd }}$ ed. Oxford: Oxford University Press, 2008.

16. Kirchner, Stefan. "Abortion and the Right to Life under Art. 2 of the European Convention on Human Rights." IUP Journal of Environment \& Health Care Law 9 (2010): 10 et seq.

17. Kirchner, Stefan. "Abortion and the Right to Life under Art. 2 of the European Convention on Human Rights?": 198 et seq. In: Asifa Begum, ed. Medical Treatment and Law. $1^{\text {st }}$ ed. India: ICFAI University Press Hyderabad, 2010.

18. Kitz, Heinz-Eberhard. Die Notstandsklausel des Art. 15 der Europäischen Menschenrechtskonvention [The emergency clause of Art. 15 of the European Convention on Human Rights]. $1^{\text {st }}$ ed. Berlin: Duncker \& Humblot, 1982.

19. Krieger, Heike. "Notstand" [Emergency]: 378 et seq. In: Rainer Grote and Thilo Marauhn, eds. Konkordanzkommentar zum europäischen und deutschen Grundrechtsschutz [Concordance commentary on European and German Protection of Basic Rights]. Tübingen: Mohr Siebeck, 2006.

20. Krüger, Hans Christian. "Reflections Concerning Accession of the European Communities to the European Convention on Human Rights." Penn State International Law Review 21 (2002): 89 et seq. 
21. Mahoney, Paul. "New Challenges for the European Court of Human Rights Resulting from the Expanding Case Load and Membership." Penn State International Law Review 21 (2002): 101 et seq.

22. Maslaton, Matthias. Notstandsklauseln im regionalen Menschenrechtsschutz: Eine vergleichende Untersuchung der Art. 15 EMRK und Art. 27 AMRK [Emergency Clauses in the regional protection of Human Rights: A comparative research of Art. 15 ECHR and Art. 27 ACHR]. $1^{\text {st }}$ ed. Frankfurt am Main: Peter Lang, 2002.

23. Matscher, Franz, and Herbert Petzold, eds. Protecting Human Rights: the European dimension: studies in honour of Gérard J. Wiarda. $2^{\text {nd }}$ ed. Cologne: Carl Heymanns Verlag, 1990.

24. Merrills, John G., and Arthur H. Robertson. Human Rights in Europe: a study of the European Convention on Human Rights. $4^{\text {th }}$ ed. Manchester: Manchester University Press, 2001.

25. Molthagen, Julia. Das Verhältnis der EU-Grundrechte zur EMRK - Eine Untersuchung unter besonderer Berücksichtigung der Charta der Grundrechte der EU [The relation of EU fundamental rights and the ECHR - An investigation with special consideration of the Charter of Fundamental Rights of the European Union]. Dissertation. Hamburg, 2003 // http://www.sub.unihamburg.de/opus/volltexte/2003/967/pdf/dissertation.pdf (accessed May 28, 2010).

26. O'Boyle, Michael. "The Margin of Appreciation and Derogation under Article 15: Ritual Incantation or Principle?" Human Rights Law Journal 19 (1998): 23 et seq.

27. Ovey, Clare. "The Margin of Appreciation and Article 8 of the Convention." Human Rights Law Journal 19 (1998): 10 et seq.

28. Ovey, Clare, and Robin C. A. White. Jacobs \& White: The European Convention on Human Rights. $4^{\text {th }}$ ed. Oxford: Oxford University Press, 2006.

29. Peters, Anne. Einführung in die Europäische Menschenrechtskonvention [Introduction to the European Convention on Human Rights]. $1^{\text {st }}$ ed. Munich: Verlag C. H. Beck, 2003.

30. Prebensen, Soren C. "The Margin of Appreciation and Articles 9, 10 and 11 of the Convention." Human Rights Law Journal 19 (1998): 13 et seq.

31. Prepeluh, Urska. "Die Entwicklung der Margin of Appreciation-Doktrin im Hinblick auf die Pressefreiheit" [The Development of the Margin of Appreciation Doctrine with regard to the freedom of the press]. Zeitschrift für ausländisches öffentliches Recht und Völkerrecht [Heidelberg Journal of International Law] 61 (2001): 771 et seq. 
32. Reid, Karen. A Practitioner's Guide to the European Convention on Human Rights. $3^{\text {rd }}$ ed. London: Sweet \& Maxwell, 2007.

33. Rupp-Swienty, Annette. Die Doktrin von der Margin of Appreciation in der Rechtsprechung des Europäischen Gerichtshofs für Menschenrechte [The Doctrine of the Margin of Appreciation in the Jurisprudence of the European Court of Human Rights]. $1^{\text {st }}$ ed. Munich: VVF-Verlag, 1999.

34. Schokkenbroeck, Jeroen. "The Basis, Nature and Application of the Margin-ofAppreciation Doctrine in the Case-law of the European Court of Human Rights." Human Rights Law Journal 19 (1998): 30 et seq.

35. Société Française pour la Droit International, ed. Les nouvelles ménaces contre la paix et la sécurité internationales [The new threats to international peace and security] (2004).

36. Stock, Susanne. Der Beitritt der Europäischen Union zur Europäischen Menschenrechtskonvention als gemischtes Abkommen? [The European Union's Accession to the European Convention on Human Rights as a mixed Agreement?]. $1^{\text {st }}$ ed. Hamburg: Verlag Dr. Kovac, 2010.

37. Strasser, Kyra. Grundrechtsschutz in Europa und der Beitritt der Euopäischen Union zur Europäischen Menschenrechtskonvention [The Protection of Fundamental Rights in Europe and the Accession of the European Union to the European Convention on Human Rights]. $1^{\text {st }}$ ed. Frankfurt am Main: Verlag Peter Lang, 2001.

38. "Strategies for Solving Global Crises - The Financial Crisis and Beyond." Göttingen Journal of International Law 2 (2010) [special issue] // http://gojil.unigoettingen.de/joomla/index.php?option=com_wrapper\&view=wrapper\&Itemid =71 (accessed May 14, 2010).

39. Talmon, Stefan. Kollektive Nichtanerkennung illegaler Staaten [Collective Non-Recognition of illegal states]. $1^{\text {st }}$ ed. Tübingen: Mohr Siebeck, 2006.

40. Van Dijk, Pieter, Fried van Hoof, Arjen van Rijn, and Leo Zwaak, eds. Theory and Practice of the European Convention on Human Rights. $4^{\text {th }}$ ed. Antwerpen, Oxford: Intersentia, 2006.

41. Villiger, Mark E. Handbuch der Europäischen Menschenrechtskonvention [Handbook of the European Convention on Human Rights]. $2^{\text {nd }}$ ed. Zürich: Schulthess Verlag, 1999.

42. Wildhaber, Luzius. The European Court of Human Rights 1998-2006: History, Achievements, Reform. $1^{\text {st }}$ ed. Kehl am Rhein: Verlag N. P. Engel, 2006.

43. Winisdoerffer, Yves. "Margin of Appreciation and Article 1 of Protocol Nr. 1." Human Rights Law Journal 19 (1998): 18 et seq. 
44. Winkler, Sebastian. Der Beitritt der Europäischen Gemeinschaften zur Europäischen Menschenrechtskonvention [The Accession of the European Communities to the European Convention on Human Rights]. $1^{\text {st }}$ ed. Baden Baden: Nomos, 2000.

45. Yourow, Howard C. The Margin of Appreciation Doctrine in the Dynamics of European Human Rights Jurisprudence. $1^{\text {st }}$ ed. Dordrecht: Martinus Nijhoff Publishers, 1996.

46. Yourow, Howard C. "The Margin of Appreciation Doctrine in the Dynamics of the Strasbourg Jurisprudence and the Construction of Europe." Zeitschrift für europarechtliche Studien [Journal for Studies in European Law] 1 (1998): 233 et seq.

\section{LEGAL REFERENCES}

1. A. and others v. Secretary of State for the Home Department. House of Lords. In: Europäische Grundrechtezeitschrift [European Fundamental Rights Journal] 32 (2005): 488 et seq.

2. A. and others $v$. United Kingdom. ECtHR Judgment of 19 February $2009 / /$ available through the HUDOC database at http://cmiskp.echr.coe.int/.

3. Adulsamet Yaman v. Turkey. ECtHR Judgment of 2 November 2004 // available through the HUDOC database at http://cmiskp.echr.coe.int/.

4. Aksoy v. Turkey. ECtHR Judgment of 18 December 1996 // available through the HUDOC database at http://cmiskp.echr.coe.int/.

5. Brannigan and McBride v. United Kingdom. ECtHR Judgment of 26 May 1993 // available through the HUDOC database at http://cmiskp.echr.coe.int/.

6. Committee of Ministers Resolution DH (70) 1.15 April 1970 // http://www.ena.lu/resolution_dh_70_committee_ministers_council_europe_1 5_april_1970-020005255.html (accessed May 28, 2010).

7. Cudak v. Lithuania. ECtHR Judgment of 23 March 2010 // available through the HUDOC database at http://cmiskp.echr.coe.int/.

8. European Convention on Human Rights [Convention for the Protection of Human Rights and Fundamental Freedoms]. ETS No. 5, 213 UNTS 221.

9. Fürst Hans-Adam II. von und zu Liechtenstein v. Germany. ECtHR Judgment of 12 July $2001 / /$ available through the HUDOC database at http://cmiskp.echr.coe.int/.

10. General Comment No. 29, States of Emergency (Article 4). Human Rights Committee, CCPR/C/21/Rev.1/Add.11, 31 August 2001.

11. Goodwin v. United Kingdom. ECtHR Judgment of 11 July 2002 // available through the HUDOC database at http://cmiskp.echr.coe.int/. 
12. Greek Case. EComHR Report. Yearbook of the European Court of Human Rights 12 (1969): 1 et seq. // available through the HUDOC database at http://cmiskp.echr.coe.int/.

13. Herczegfalvy v. Austria. ECtHR Judgment of 24 September 1992 // available through the HUDOC database at http://cmiskp.echr.coe.int/.

14. I. v. United Kingdom. ECtHR Judgment of 11 July 2002 // available through the HUDOC database at http://cmiskp.echr.coe.int/.

15. Ireland v. United Kingdom. ECtHR Judgment of 18 January 1978 // available through the HUDOC database at http://cmiskp.echr.coe.int/.

16. Kjeldsen, Busk Madsen and Pedersen v. Denmark. ECtHR Judgment of 7 December 1976 // available through the HUDOC database at http://cmiskp.echr.coe.int/.

17. Lawless v. Ireland. ECtHR Judgment of 1 July $1961 / /$ available through the HUDOC database at http://cmiskp.echr.coe.int/.

18. PACE President in favour of strengthening relations with Kazahkstan. Council of Europe Parliamentary Assembly, 16 March 2010 // http://assembly.coe.int/ASP/NewsManager/EMB_NewsManagerView.asp?ID=5 361\&L=2 (accessed May 28, 2010).

19. Podkolzina v. Lithuania. ECtHR Judgment of 9 April 2002 // available through the HUDOC database at http://cmiskp.echr.coe.int/.

20. Reference re Secession of Quebec. Supreme Court (Canada) Decision of 30 September 1996 [1998]. 2 S.C.R. 217.

21. Report of the Group of Wise Persons to the Committee of Ministers. Council of Europe, CM (2006) 2003, 15 November 2006.

22. Resolution 1113 (1997) on the Situation in Cyprus. Council of Europe Parliamentary Assembly, 29 January 1997 // http://assembly.coe.int/Main.asp?link=/Documents/AdoptedText/ta97/ERES1 113.htm (accessed May 28, 2010).

23. Sakik and others v. Turkey. ECtHR Judgment of 26 November 1997 // available through the HUDOC database at http://cmiskp.echr.coe.int/.

24. Sener v. Turkey. ECtHR Judgment of 18 July $2000 / /$ available through the HUDOC database at http://cmiskp.echr.coe.int/.

25. Situation in Kazahkstan and its relations with the Council of Europe. Council of Europe Parliamentary Assembly, Council of Europe Document 11007, 7 July $2006 / /$ http://assembly.coe.int/Main.asp?link=/Documents/WorkingDocs/Doc06/EDO C11007.htm (accessed May 28, 2010).

26. Sunday Times v. United Kingdom. ECtHR Judgment of 26 April 1979 // available through the HUDOC database at http://cmiskp.echr.coe.int/. 
27. Vienna Convention on the Law of Treaties. 1155 United Nations Treaty Series 331. 